\title{
JENIS-JENIS TUMBUHAN BERKHASIAT OBAT TRADISIONAL DI MASYARAKAT DESA YANIM DAN BRASO DISTRIK KEMTUK GRESI KABUPATEN JAYAPURA
}

\section{THE KIND OF PLANTS TO USE AS TRADITIONAL MEDICINE FOR PEOPLE WHO LIVE AT VILLAGE OF YANIM AND BRASO, DISTRICT OF KEMTUK GRESI OF JAYAPURA REGENCY}

\author{
Sophia Marcelina Yansip, Elis Tambaru, Muhtadin Asnady Salam \\ Departemen Biologi, Fakultas Matematika dan IImu Pengetahuan Alam \\ Universitas Hasanuddin, Makassar, 90245 \\ sophiayansip@gmail.com
}

\begin{abstract}
Abstrak
Penelitian jenis-jenis tumbuhan berkhasiat obat tradisional di masyarakat Desa Yanim dan Braso, Distrik Kemtuk Gresi, Kabupaten Jayapura, telah dilaksanakan pada bulan Desember 2016 - Januari 2017, yang bertujuan untuk mengetahui jenis-jenis tumbuhan berkhasiat obat tradisional yang dimanfaatkan oleh masyarakat di Desa Yanim dan Braso Distrik Kemtuk Gresi Kabupaten Jayapura. Identifikasi sampel tumbuhan dilakukan di Laboratorium Botani, Departemen Biologi, Fakultas Matematika dan IImu Pengetahuan Alam, Universitas Hasanuddin, Makassar. Jenis penelitian ini adalah eksploratif yang bersifat deskriptif yang dilakukan dengan metode jelajah Cruised method, sedangkan informasi mengenai pemanfaatan tumbuhan obat dilakukan dengan metode Participatory Rural Appraisal yang berupa kuisioner. Hasil penelitian menunjukkan bahwa jenis-jenis tumbuhan yang dimanfaatkan oleh masyarakat Desa Yanim dan Braso Distrik Kemtuk Gresi Kabupaten Jayapura menunjukkan bahwa jumlah keseluruhan tumbuhan yang dimanfaatkan oleh masyarakat desa desa setempat adalah 57 jenis tumbuhan dari 35 Familia dan 2 Classis yaitu Monocotyledoneae dan Dicotyledoneae. Jumlah jenis tumbuhan obat yang dimanfaatkan di Desa Yanim yaitu 30 jenis dan di Desa Braso 55 jenis. Organ tumbuhan yang paling banyak dimanfaatkan adalah daun $(66,7 \%)$ dan yang paling sedikit adalah biji $(1,78 \%)$. Cara pengolahan tumbuhan obat yang paling banyak dilakukan dengan cara direbus $(71,4 \%)$ dan paling sedikit dengan cara dikunyah $(3,57 \%)$ dan diremas-remas $(3,57 \%)$.
\end{abstract}

Kata kunci: Tumbuhan obat tradisional, Desa Yanim Braso, Jayapura

\section{Abstract}

A research on plants to use as traditional medicine for people who live at Village of Yanim and Braso, District of Kemtuk Gresi of Jayapura Papua had been done from December 2016 to January 2017. The aim of this research want to know the function of those plants as traditional medicine for rural which grow in that Village mention above. Plants identification were done at Laboratory of Botany, Departement of Biology, Faculty of Science and Mathematics, Hasanuddin University, Makassar. Explorative research with descriptive study and Crussial Method than the information for the medicine plants has done by using Participatory Rural Appraisal Method and also quistionaire. The result shows that from the Class of Monocotyledoneae and Dicotyledoneae were found 57 species of plants in 34 families. 30 species were found at Yanim Village and 54 species at Braso Village respectially. The leaf as a plant of plant were mostly used $(66,7 \%)$ and seed as the less $(1,78 \%)$ as traditional medicine. The way of process it by boiling $(73,2 \%)$, chewing $(3,57 \%)$ and by kneading $(3,57 \%)$.

Key words : Traditional medicine plants, Village of Yanim and Braso, Jayapura 


\section{Pendahuluan}

Kesehatan merupakan salah satu kebutuhan dasar manusia, di samping kebutuhan akan sandang, pangan, papan dan pendidikan, karena hanya dengan kondisi kesehatan yang baik serta tubuh yang prima manusia dapat melaksanakan proses kehidupan untuk tumbuh dan berkembang menjalankan segala aktivitas hidupnya (Katno dan Pramono, 2006). Salah satu cara untuk menjaga kesehatan masyarakat untuk menyembuhkan penyakit dengan menggunakan potensi tumbuhan yang berkhasiat obat. Tumbuhan obat menjadi bahan utama obat-obatan yang menjadi sumber penting yang dapat dimanfaatkan oleh manusia untuk mencapai tujuan kesehatan. Pengetahuan tentang tumbuhan obat dan penggunaannya telah diwariskan secara turun-temurun dari generasi ke generasi.

Indonesia merupakan negara tropis yang kaya akan sumber bahan obat alam dan obat tradisional yang telah digunakan oleh sebagian besar masyarakat Indonesia secara turun-temurun. Keuntungan obat tradisional yang dirasakan langsung oleh masyarakat adalah kemudahan untuk memperoleh bahan bakunya dan bahan bakunya dapat ditanam di pekarangan sendiri, mudah dan dapat diramu sendiri di rumah. Masyarakat di Indonesia menggunakan tumbuhan obat untuk mengobati penyakit atau kelainan yang timbul pada tubuh selama hidupnya, baik ketika masih bayi, kanak-kanak, maupun setelah dewasa (Umar, 2005).

Provinsi Papua merupakan daerah tropis terluas dan tertinggi keanekaragaman hayati di dunia yang masih kurang dikelola dan dimanfaatkan secara maksimal (Kawengian dan Rumahorbo, 2009). Hasil penelitian di berbagai wilayah di Papua menunjukkan, bahwa pemanfaatan tumbuhan sebagai bahan obat tradisional di Papua cukup tinggi, dan setiap daerah mempunyai potensi yang berbeda. Keragaman tumbuhan khususnya vegetasi nonkayu dimanfaatkan oleh masyarakat untuk berbagai keperluan termasuk bahan pangan, bangunan dan perabot rumah tangga, obatobatan, senjata tradisional, kerajinan tangan, dan tanaman hias (Sada dan Rosye, 2010). Kabupaten Jayapura memiliki potensi jenis-jenis tumbuhan obat tradisional, sehingga dilakukanlah penelitian ini. Salah satu kawasan yang dinilai berpotensi adalah Distrik Kemtuk Gresi, tepatnya pada dua desa yaitu Desa Yanim dan Braso. Letak kedua desa ini cukup jauh dari perkotaan, sehingga penduduk desa setempat seringkali menggunakan tumbuh-tumbuhan berkahasiat obat sebagai alternatif yang sangat tepat untuk pengobatan penyakit secara tradisional. Desa Yanim dan Braso Distrik Kemtuk Gresi Kabupaten Jayapura merupakan dua dari beberapa desa yang memiliki keragaman flora yang tinggi. Sebagaimana umumnya desa yang berada di Distrik Kemtuk Gresi, mayoritas penduduknya adalah petani. Masyarakat pada kedua lokasi di atas untuk mengatasi masalah kesehatan, mereka masih mengandalkan pengetahuan tumbuhan obat secara turun-temurun dari nenek moyang mereka dengan memanfaatkan bahan alam berupa penggunaan obat-obat dari tumbuhan. Hamparan hutan di sekeliling pemukiman penduduk merupakan anugerah tersendiri sebagai apotik hidup bagi warga desa tersebut. Berdasarkan uraian di atas, maka dilakukan penelitian tentang jenis-jenis tumbuhan obat di Desa Yanim dan Braso Distrik Kemtuk Gresi Kabupaten Jayapura. Penelitian ini dimaksudkan untuk melihat jenis-jenis tumbuhan yang berkhasiat sebagai obat tradisional. Penelitian ini bertujuan untuk mengetahui jenis-jenis tumbuhan berkhasiat obat tradisional yang dimanfaatkan oleh masyarakat di Desa Yanim dan Braso Distrik Kemtuk Gresi Kabupaten Jayapura. 
Metode Penelitian

Penelitian ini dilakukan pada bulan Desember 2016-Januari 2017. Pengambilan sampel dilakukan di Desa Yanim dan Braso, Distrik Kemtuk Gresi, Kabupaten Jayapura. Identifikasi sampel di Laboratorium Botani, Departemen Biologi, Fakultas Matematika dan IImu Pengetahuan Alam, Universitas Hasanuddin. Alat yang digunakan dalam penelitian ini adalah alat tulis menulis, penggaris, peralatan herbarium, Global Positioning System (GPS), kamera, dan peta lokasi penelitian. Bahan yang digunakan pada penelitian ini adalah tumbuhan yang berkhasiat obat, alkohol $70 \%$, buku identifikasi flora, kertas koran, selotip, kertas label, plastik sampel, dan daftar tabel wawancara.

Jenis penelitian ini adalah eksploratif yang bersifat deskriptif. Menurut Fatoni (2006), metode deskriptif (survey) merupakan penelitian yang bertujuan untuk memperoleh fakta dari gejala yang ada dan mencari faktual dari suatu kelompok atau daerah yang dilakukan dengan terhadap sejumlah individu atau unit, baik secara sensus maupun dengan menggunakan sampel. Jenis data yang dikumpulkan dalam penelitian ini berupa data kuantitatif dan kualitatif, data primer yang diteliti meliputi jenis dan jumlah tumbuhan obat, nama lokal, bagian tumbuhan yang dimanfaatkan, jenis penyakit yang dapat diobati, dan cara pengolahannya. Data primer dikumpulkan secara selektif dan sistematis dengan menjelajahi lokasi penelitian menggunakan metode jelajah Cruise Method (Lucas dan Maxey, 2006). Pengambilan sampel tumbuhan obat pada daerah sekitar tapak jelajah yang dilalui dilakukan dengan metode Participatory Rural Appraisal merupakan proses pengkajian yang memungkingkan keterlibatan masyarakat desa secara aktif (Cavestro, 2003). Keterlibatan masyarakat diperoleh melalui wawancara instruktur interview guide dengan penduduk setempat yang berpedoman pada daftar pertanyaan (quisioner) terlampir untuk mengetahui jumlah spesies tumbuhan yang telah dimanfaatkan untuk pengobatan. Sampel tumbuhan yang telah diperoleh dari masyarakat kemudian didokumentasi dan diidentifikasi di Laboratorium Botani Fakultas Matematika dan IImu Pengetahuan Alam. Identifikasi tumbuhan didasarkan pada karakteristik morfologi dari sampel dengan mengacu pada beberapa buku-buku literatur tentang tumbuhan obat.

Data tumbuhan obat yang diperoleh melalui hasil penjelajahan dan wawancara dengan anggota masyarakat desa diolah secara deskriptif dengan cara dikelompokkan, ditabulasi, disajikan dalam bentuk tabel. Selanjutnya data dianalisis untuk mendapatkan gambaran umum mengenai jenis-jenis tumbuhan obat yang tumbuh di Desa Yanim dan Braso, Distrik Kemtuk Gresi dan pemanfaatannya sebagai obat tradisional bagi masyarakat.

\section{Hasil dan Pembahasan}

1. Jenis-jenis Tumbuhan Obat yang Ditemukan di Desa Yanim dan Braso, Distrik Kemtuk Gresi Kabupaten Jayapura

Berdasarkan hasil penelitian yang dilakukan dengan metode jelajah Cruise Method di Desa Yanim dan Braso, maka ditemukan berbagai jenis-jenis tumbuhan yang ditemukan di Desa Yanim dan Braso sangat beragam mulai dari pohon, perdu, semak dan herba. Jumlah tumbuhan obat yang dimanfaatkan oleh masyarakat yaitu 57 jenis, yang terdiri dari 41 jenis tumbuhan Dicotyledoneae dan 16 jenis tumbuhan Monocotyledoneae, 35 Familia dan 51 Genus (dapat dilihat pada Tabel 1). Jenis-jenis 
tumbuhan obat tradisional yang dimanfaatkan oleh masyarakat hampir sebagain besar ditemukan tumbuh liar maupun dibudidayakan di pekarangan rumah dan kebun.

Jenis tumbuhan obat dari Classis Dicotyledoneae yang dimanfaatkan oleh masyarakat Desa Yanim dan Braso terdiri dari 27 Familia yaitu Moraceae, Urticaceae, Piperaceae, Loranthaceae, Cactaceae, Euphorbiaceae, Annoaceae, Lauraceae, Crassulaceae, Mimosaceae, Caesapiniaceae, Combretaceae, Myrtaceae, Thymelaeaceae, Caricaceae, Tiliaceae, Bombacaceae, Malvaceae, Oxalidaceae, Rutaceae, Sapindaceae, Anacardiaceae, Rubiaceae, Apocynaceae, Acanthaceae, Lamiaceae, dan Cucurbitaceae. Jumlah tumbuhan obat yang paling banyak digunakan yaitu 4 (empat) jenis tumbuhan dari Familia Urticaceae yang terdiri dari: Dendrocnide peltata, Laportea decumana, Laportea interrupta dan Laportea sp., Familia Piperaceae yaitu Piper betle, Peperomia pellucida, Piper crocatus dan Piper aduncum dan Familia Euphorbiaceae yaitu Phyllantus urinaria, Ricinus communia, Jatropha gossypifilia, dan Pedilanthus tithymaloides.

Jenis tumbuhan Classis Monocotyledoneae yang dimanfaatkan oleh masyarakat Desa Yanim dan Braso adalah jenis tumbuhan dari 8 (delapan) Familia Liliaceae, Amaryllidaceae, Poaceae, Musaceae, Zingiberaceae, Orchidaceae, Arecaceae, dan Pandanaceae. Jumlah tumbuhan obat yang paling banyak digunakan yaitu 6 (enam) jenis tumbuhan dari Familia Zingiberaceae yang teridiri dari: Zingiber officinale Rosc, Zingiber officinale Roxb. var. rubra, Curcuma domestica, Curcuma xanthorrhiza, Etlingera elatior, dan Apinia galanga. Pemanfaatan Tumbuhan sebagai Obat oleh Masyarakat di Desa Yanim dan Braso, Distrik Kemtuk Gresi Kabupaten Jayapura (Tabel 1).

Tabel 1. Persentase Pemakaian Tumbuhan Obat Setiap Species di Masyarakat Desa Yanim dan Braso

\begin{tabular}{|c|c|c|c|c|c|c|}
\hline \multirow[b]{2}{*}{$\begin{array}{l}\mathrm{N} \\
\mathrm{O}\end{array}$} & \multirow{2}{*}{$\begin{array}{c}\text { Jenis } \\
\text { Tumbuhan }\end{array}$} & \multirow[b]{2}{*}{ Nama IImiah } & \multirow{2}{*}{$\begin{array}{l}\text { Organ yang } \\
\text { dimanfaatkan }\end{array}$} & \multirow[b]{2}{*}{ Khasiat } & \multicolumn{2}{|c|}{ Persentase (\%) } \\
\hline & & & & & $\begin{array}{l}\text { Desa } \\
\text { Yanim }\end{array}$ & $\begin{array}{l}\text { Desa } \\
\text { Braso }\end{array}$ \\
\hline 1 & Nangka & $\begin{array}{l}\text { Artocarpus } \\
\text { heterophylla Lamk. }\end{array}$ & Daun & $\begin{array}{l}\text { Pegal-pegal, } \\
\text { rematik, asam urat }\end{array}$ & 3,3 & - \\
\hline 2 & $\begin{array}{l}\text { Daun gatal } \\
\text { ungu }\end{array}$ & $\begin{array}{l}\text { Dendrocnide peltata } \\
\text { (Bl.) Miq }\end{array}$ & Daun & $\begin{array}{l}\text { Pegal-pegal, } \\
\text { malaria }\end{array}$ & 43,3 & 33,3 \\
\hline 3 & $\begin{array}{l}\text { Daun gatal } \\
\text { hijau }\end{array}$ & $\begin{array}{l}\text { Laportea interrupta } \\
\text { (L.) Chew. }\end{array}$ & Daun & $\begin{array}{l}\text { Pegal-pegal, } \\
\text { malaria }\end{array}$ & 73,3 & 66,67 \\
\hline 4 & $\begin{array}{l}\text { Daun gatal } \\
\text { bintik putih }\end{array}$ & $\begin{array}{l}\text { Laportea decumana } \\
\text { (Roxb.) Wedd. }\end{array}$ & Daun & $\begin{array}{l}\text { Pegal-pegal, } \\
\text { malaria }\end{array}$ & 73,3 & 66,67 \\
\hline 5 & $\begin{array}{l}\text { Daun gatal } \\
\text { babi }\end{array}$ & Laportea sp. & Daun & $\begin{array}{l}\text { Patah tulang, } \\
\text { melancarkan } \\
\text { peredaran darah } \\
\text { pada penderita } \\
\text { stroke }\end{array}$ & 10 & 10 \\
\hline 6 & Sirih-sirihan & $\begin{array}{l}\text { Peperomia pellucida } \\
\text { (L.) Kunth. }\end{array}$ & Seluruh bagian & Limpa, ginjal & - & 6,67 \\
\hline 7 & Sirih & Piper betle L. & Daun & $\begin{array}{l}\text { Batuk, jerawat, } \\
\text { menghilangkan bau } \\
\text { mulut, }\end{array}$ & 3,3 & 20 \\
\hline 8 & Sirih merah & $\begin{array}{l}\text { Piper crocatus Ruiz } \\
\& \text { Pav. }\end{array}$ & Daun & Batuk & - & 3,3 \\
\hline 9 & $\begin{array}{l}\text { Seuseureuha } \\
\mathrm{n}\end{array}$ & Piper aduncum L. & Daun & Luka & 6,67 & 3,3 \\
\hline 10 & Benalu & Loranthus sp. & Daun & Paru-paru basa & - & 3,3 \\
\hline 11 & $\begin{array}{l}\text { Wiyaja } \\
\text { Kusuma }\end{array}$ & $\begin{array}{l}\text { Epiphyllum } \\
\text { anguliger }\end{array}$ & Daun & $\begin{array}{l}\text { Bisul, penyakit } \\
\text { dalam }\end{array}$ & - & 3,3 \\
\hline
\end{tabular}




\begin{tabular}{|c|c|c|c|c|c|c|}
\hline & & & & & & \\
\hline 12 & Meniran & $\begin{array}{l}\text { Phyllanthus urinaria } \\
\text { Linn. }\end{array}$ & Seluruh bagian & $\begin{array}{l}\text { Diare, malaria, } \\
\text { sakit tulang }\end{array}$ & 13,3 & 3,3 \\
\hline 13 & Jarak & $\begin{array}{l}\text { Ricinus communis } \\
\text { Merr. }\end{array}$ & Daun dan getah & Sakit gigi, kudis & 6,67 & 6,67 \\
\hline 14 & Jarak merah & $\begin{array}{l}\text { Jatropha } \\
\text { gossypifolia L. }\end{array}$ & Getah & Luka & 3,3 & 3,3 \\
\hline 15 & Pohon lipan & $\begin{array}{l}\text { Pedilanthus } \\
\text { tithymaloides L. }\end{array}$ & Getah & Luka & - & 6,67 \\
\hline 16 & Sirsak & Annona muricata $\mathrm{L}$. & Daun & $\begin{array}{l}\text { Pegal-pegal, } \\
\text { penyakit lambung, } \\
\text { sakit lutut }\end{array}$ & 20 & 20 \\
\hline 17 & Alfokat & $\begin{array}{l}\text { Persea Americana } \\
\text { Mill. }\end{array}$ & Daun & Diare & - & 3,3 \\
\hline 18 & Cocor bebek & $\begin{array}{l}\text { Bryophyllum pinnata } \\
\text { (Lam.) Oken }\end{array}$ & Daun & $\begin{array}{l}\text { Batuk, demam, } \\
\text { katarak }\end{array}$ & 10 & 16,67 \\
\hline 19 & Cocor bebek & $\begin{array}{l}\text { Kalanchoe pinnata } \\
\text { (Lam.) Pers. }\end{array}$ & Daun & $\begin{array}{l}\text { Batuk, demam, } \\
\text { katarak }\end{array}$ & 10 & 10 \\
\hline 20 & Putri malu & Mimosa pudica L. & Seluruh bagian & Paru-paru & 6,67 & - \\
\hline 21 & Ketepeng & Cassia alata L. & Daun & $\begin{array}{l}\text { Insomnia, penyakit } \\
\text { kulit, bengkak }\end{array}$ & - & 10 \\
\hline 22 & Ketapang & $\begin{array}{l}\text { Terminalia catappa } \\
\text { Linn. }\end{array}$ & $\begin{array}{l}\text { Daun dan kulit } \\
\text { batang }\end{array}$ & $\begin{array}{l}\text { Limpa, rematik, } \\
\text { ginjal }\end{array}$ & - & 13,3 \\
\hline 23 & Kayu putih & $\begin{array}{l}\text { Melaleuca } \\
\text { leucadendra L. }\end{array}$ & Daun & Pegal-pegal & - & 3,3 \\
\hline 24 & Jambu Biji & Psidium gujava L. & Daun muda & Diare, flu, batuk, & 26,67 & 16,67 \\
\hline 25 & Jambu Air & $\begin{array}{l}\text { Syzygium aquea } \\
\text { Burm. } f\end{array}$ & Daun & Pegal-pegal & - & 3,3 \\
\hline 26 & $\begin{array}{l}\text { Mahkota } \\
\text { Dewa }\end{array}$ & $\begin{array}{l}\text { Phaleria } \\
\text { macrocarpa } \\
\text { (Scheff.) Boerl. }\end{array}$ & Daun dan biji & $\begin{array}{l}\text { Asma, asam urat, } \\
\text { kolesterol }\end{array}$ & - & 10 \\
\hline 27 & Pepaya & Carica papaya L. & Daun dan getah & Malaria, kadas & 13,3 & 13,3 \\
\hline 28 & $\begin{array}{l}\text { Kersen } \\
\text { Belanda }\end{array}$ & Apeiba sp. & Kulit batang & Bisul, ginjal & - & 10 \\
\hline 29 & Kapuk randu & $\begin{array}{l}\text { Ceiba pentandra } \\
\text { Gaertn. }\end{array}$ & Kulit batang & Paru-paru basah & - & 3,3 \\
\hline & & & & & & \\
\hline 30 & Sidaguri & $\begin{array}{l}\text { Sida rhombifolia } \\
\text { Linn. }\end{array}$ & Akar & $\begin{array}{l}\text { Ginjal, paru-paru } \\
\text { basah }\end{array}$ & & \\
\hline 31 & $\begin{array}{l}\text { Belimbing } \\
\text { Wuluh }\end{array}$ & Averrhoa bilimbi L. & Buah & Batuk, asma & - & 3,3 \\
\hline 32 & Jeruk nipis & $\begin{array}{l}\text { Citrus } \\
\text { Swingle }\end{array}$ & Daun dan buah & Pegal-pegal, batuk & 6,67 & 20 \\
\hline 33 & Matoa & $\begin{array}{l}\text { Pometia pinnata } \\
\text { J.R.\& G.Forst }\end{array}$ & $\begin{array}{l}\text { Kulit batang dan } \\
\text { daun }\end{array}$ & $\begin{array}{l}\text { Paru-paru basah, } \\
\text { rematik }\end{array}$ & 16,67 & 10 \\
\hline 34 & $\begin{array}{l}\text { Jambu } \\
\text { monyet }\end{array}$ & $\begin{array}{l}\text { Anacardium } \\
\text { occidentale } \mathrm{L} .\end{array}$ & Daun & $\begin{array}{l}\text { Pegal-pegal, } \\
\text { rematik, asam urat }\end{array}$ & - & 3,3 \\
\hline 35 & Mengkudu & Morinda citrifolia L. & $\begin{array}{l}\text { Daun, buah, } \\
\text { getah dan kulit } \\
\text { batang }\end{array}$ & $\begin{array}{l}\text { Batuk, malaria, } \\
\text { demam }\end{array}$ & 16,67 & 3,3 \\
\hline 36 & Kayu perahu & $\begin{array}{l}\text { Nauclea latifolia } \\
\text { (Egbesi) }\end{array}$ & Kulit batang & $\begin{array}{l}\text { Pegal-pegal, } \\
\text { penyakit limpa, } \\
\text { lambung basa }\end{array}$ & 16,67 & 3,3 \\
\hline 37 & Pulai & $\begin{array}{l}\text { Alstonia scholaris } \\
\text { (L.) R.Br }\end{array}$ & $\begin{array}{l}\text { Kulit batang dan } \\
\text { getah }\end{array}$ & Diare & 13,3 & 3,3 \\
\hline 38 & Sambiloto & $\begin{array}{l}\text { Andrographis } \\
\text { paniculata (Burm. } \\
\text { F.) Wallich ex Nees }\end{array}$ & $\begin{array}{l}\text { Daun dan } \\
\text { batang }\end{array}$ & $\begin{array}{l}\text { Malaria, diare, } \\
\text { demam tulang }\end{array}$ & 3,3 & 13,3 \\
\hline 39 & Miyana & $\begin{array}{l}\text { Coleus } \\
\text { scutelarioides (L.) } \\
\text { Bth }\end{array}$ & Daun & Paru-paru basa & 10 & 20 \\
\hline
\end{tabular}




\begin{tabular}{|c|c|c|c|c|c|c|}
\hline 40 & Kumis Kucing & $\begin{array}{l}\text { Orthosiphon } \\
\text { stamineus B.B.S. }\end{array}$ & Daun & $\begin{array}{l}\text { Malaria, pegal- } \\
\text { pegal, rematik }\end{array}$ & 6,67 & 10 \\
\hline 41 & Paria & $\begin{array}{l}\text { Momordica } \\
\text { charantia Linn. }\end{array}$ & Daun & Paru-paru & 3,3 & - \\
\hline 42 & Lidah buaya & Aloe vera $\mathrm{L}$. & Daun & Bisul & - & 6,67 \\
\hline 43 & $\begin{array}{l}\text { Bunga } \\
\text { Bakung }\end{array}$ & Crinum asiaticum L. & Daun & Sakit lutut & - & 3,3 \\
\hline 44 & Serai & $\begin{array}{l}\text { Andropogon } \\
\text { nardusL. }\end{array}$ & Rimpang & $\begin{array}{l}\text { Sakit gigi, pegal- } \\
\text { pegal }\end{array}$ & 3,3 & 3,3 \\
\hline 45 & Alang-alang & $\begin{array}{l}\text { Imperata cylindrica } \\
\text { (L.) P. Beauv. }\end{array}$ & Akar & Penyakit ginjal & - & 3,3 \\
\hline 46 & $\begin{array}{l}\text { Rumput } \\
\text { belulang }\end{array}$ & Eleusine indica L. & Seluruh bagian & $\begin{array}{l}\text { Muntaber pada } \\
\text { anak-anak }\end{array}$ & 3,3 & 6,67 \\
\hline 47 & Pisang & Musa paradisiaca L. & Buah dan daun & Diare, pegal-pegal & 6,67 & - \\
\hline 48 & Jahe merah & $\begin{array}{l}\text { Zingiber officinale } \\
\text { Roxb. var. rubra }\end{array}$ & Rimpang & Sakit gigi, rematik & 3,3 & 20 \\
\hline 49 & Jahe putih & $\begin{array}{l}\text { Zingiber officinale } \\
\text { Rosc. }\end{array}$ & Rimpang & Katarak, rematik & 3,3 & 6,67 \\
\hline 50 & Kunyit & $\begin{array}{l}\text { Curcuma domestica } \\
\text { Rumph. }\end{array}$ & Rimpang & $\begin{array}{l}\text { Sakit lutut, tulang } \\
\text { belakang }\end{array}$ & - & 6,67 \\
\hline 51 & Temulawak & $\begin{array}{l}\text { Curcuma } \\
\text { xanthorrhiza Roxb. }\end{array}$ & Rimpang & $\begin{array}{l}\text { Keseleo, batuk, } \\
\text { paru-paru basah }\end{array}$ & - & 6,67 \\
\hline 52 & Kecombrang & $\begin{array}{l}\text { Etlingera elatior } \\
\text { Jack. }\end{array}$ & Kulit batang & $\begin{array}{l}\text { Menurunkan kadar } \\
\text { gula darah }\end{array}$ & - & 3,3 \\
\hline 53 & Lengkuas & $\begin{array}{l}\text { Alpinia galanga (L.) } \\
\text { Sw. }\end{array}$ & Rimpang & Kadas, panu & - & 3,3 \\
\hline 54 & Anggrek & Dendrobium sp. & Buah & Luka & - & 3,3 \\
\hline 55 & Pinang & Areca catechu Linn. & Buah dan akar & $\begin{array}{l}\text { Menghilangkan bau } \\
\text { mulut, sakit lutut } \\
\text { dan pinggang }\end{array}$ & 3,3 & 3,3 \\
\hline 56 & Sagu & $\begin{array}{l}\text { Metroxylon sago } \\
\text { Rottb. }\end{array}$ & Pati & Diare & 3,3 & - \\
\hline 57 & Buah merah & $\begin{array}{l}\text { Pandanus } \\
\text { conoideus Lam. }\end{array}$ & Buah & Penyakit dalam & - & 3,3 \\
\hline
\end{tabular}

Berdasarkan hasil wawancara (interview) terhadap 60 orang anggota masyarakatdi Desa Yanim dan Braso, dapat dilihat bahwa sebagian besar masyarakat di kedua desa tersebut masih sangat bergantung pada penggunaan tumbuhan obat untuk mengatasi berbagai masalah kesehatan. Hasil wawancara dengan masyarakat yang diperoleh yaitu mengenai jenis tumbuhan obat (nama Indonesia dan nama lokal Kemtuk Gresi) yang dimanfaatkan, bagian tumbuhan yang digunakan, penyakit yang diobati menggunakan tumbuhan tersebut dan cara mengolah tumbuhan tersebut menjadi ramuan obat tradisional (dapat dilihat pada Tabel 3). Jumlah tumbuhan obat yang dimanfaatkan pada masyarakat Desa Yanim yaitu 30 jenis dan di masyarakat Desa Braso sebanyak 55 jenis (dapat dilhat pada Tabel 3). Jenis tumbuhan yang paling banyak digunakan yaitu pada masyarakat Desa Braso karena masyarakat desa ini masih menggunakan bahan-bahan alam yang bersifat tradisional, selain itu masyarakat di Desa Braso juga tidak memiliki sarana kesehatan seperti Polindes yang terdapat di Desa Yanim, sehingga masyarakat cenderung menggunakan potensi tumbuhan obat untuk mengobati penyakit yang dialaminya.

Jumlah tumbuhan obat yang dimanfaatkan pada masyarakat Desa Yanim yaitu 30 jenis dan di masyarakat Desa Braso sebanyak 55 jenis (dapat dilhat pada Tabel 3). Jenis tumbuhan yang paling banyak digunakan yaitu pada masyarakat Desa Braso karena masyarakat desa ini masih menggunakan bahan-bahan alam yang bersifat tradisional, selain itu masyarakat di Desa Braso juga tidak memiliki sarana kesehatan seperti Polindes yang terdapat di Desa Yanim, sehingga masyarakat cenderung menggunakan potensi tumbuhan obat untuk mengobati penyakit yang dialaminya. 
Menurut Darnaedi dan Nizma (1995), masyarakat tradisional saat ini lebih cenderung menggunakan obat tradisional yang bersumber dari alam dan sebagian dari tumbuhan obat potensial yang diperkirakan mengandung senyawa bioaktif berkhasiat obat. Organ tumbuhan Dicotyledoneae yang dimanfaatkan oleh masyarakat adalah akar, batang, kulit batang, daun, getah, bunga, buah, dan biji. Organ tumbuhan yang paling banyak dimanfaatkan adalah daun. Menurut hasil diskusi dengan masyarakat desa setempat percaya bahwa senyawa kimia pada tumbuhan paling banyak terkandung pada daun dibandingkan pada organ lainnya, sehingga masyarakat cenderung menggunakan daun sebagai bahan obat tradisional. Organ tumbuhan Monocotyledoneae yang digunakan sebagai obat adalah akar, rimpang, batang, daun, dan buah. Organ tumbuhan yang paling banyak digunakan adalah rimpang dari 7 (tujuh) jenis tumbuhan. Persentase jumlah penggunaan organ tumbuhan yang dimanfaatkan oleh masyarakat yaitu akar $(12,5 \%)$, rimpang $(10,7 \%)$, batang $(8,29 \%)$, kulit batang $(14,2 \%)$, daun $(66,7 \%)$, getah $(10,7 \%)$, bunga $(5,35 \%)$, buah $(12,5 \%)$, dan biji $(1,78 \%)$. Hal ini menunjukkan bahwa organ tumbuhan yang paling banyak digunakan adalah daun $(66,7 \%)$ dan paling sedikit adalah biji $(1,78 \%)$.

Menurut Setyowati (2010), daun lebih banyak digunakan sebagai obat karena daun lebih mudah didapatkan jika dibandingkan organ lain dari tumbuhan. Hasil penelitian Hidayat (2012), menunjukkan bahwa kandungan senyawa metabolit sekunder paling seperti saponin, flavonoid, steroid, dan minyak atsiri cenderung lebih banyak pada daun dibandingkan pada organ lainnya. Organ tumbuhan Dicotyledoneae yang dimanfaatkan oleh masyarakat adalah daun, batang, kulit batang, getah, bunga, buah, biji serta akar dan bagian tumbuhan yang paling banyak dimanfaatkan adalah daun. Menurut hasil diskusi dengan masyarakat desa setempat percaya bahwa senyawa kimia pada tumbuhan paling banyak terkandung pada daun dibandingkan pada organ lainnya, sehingga masyarakat cenderung menggunakan daun sebagai bahan obat tradisional. Organ tumbuhan Monocotyledoneae yang digunakan sebagai obat adalah daun, buah, pati, akar serta rimpang dan bagian tumbuhan yang paling banyak digunakan adalah rimpang dari 7 (tujuh) jenis tumbuhan.

Akar yang digunakan adalah dari tumbuhan sidaguri Sida rhombifolia, masyarakat di Desa Braso memanfaatkan sidaguri untuk mengobati kelainan pada ginjal dan paru-paru. Sidaguri juga bermanfaat untuk mengobati rematik, diare, meluruhkan air seni dan meningkatkan stamina tubuh. Hasil penelitian Sundaraganapathy et al. (2013) menunjukkan bahwa akar sidaguri mengandung beberapa senyawa kimia antara lain alkaloid, flavonoid dan fenolik. Rimpang yang digunakan adalah dari tanaman jahe merah Zinngiber officinale Roxb, masyarakat di Desa Yanim dan Braso memanfaatkan jahe merah untuk mengobati sakit gigi dan rematik. Jahe merah juga dimanfaatkan untuk mengobati dingin, antirematik, batuk, afrodisiak, asma, dan menstimulasi sistem kekebalan tubuh (Pratiwi et al. 2015). Hasil penelitian Gupta dan Sharma (2014) menunjukkan bahwa rimpang jahe merah mengandung beberapa senyawa kimia antara lain zingeberin, kurkumin dan antioksidan. Kulit batang yang digunakan adalah dari tanaman matoa Pometia pinnata, masyarakat di Desa Yanim dan Braso memanfaatkan matoa yaitu untuk mengobati penyakit paru-paru basa, rematik dan pegal-pegal, matoa juga bermanfaat untuk mengobati mengobati infeksi mulut, diare dan disentri. Hasil penelitian Trimedona et al. (2015) menunjukkan bahwa kulit batang mengandung beberapa senyawa kimia antara lain saponin, triterpenoid dan fenolik.Daun yang digunakan adalah dari tanaman sirsak Annona muricata dan Daun gatal bintik putih Laportea interrupta, masyarakat di Desa Yanim dan Braso memanfaatkan sirsak untuk mengobati, batuk berdahak, penyakit lambung dan sakit lutut serta tulang. Sirsak juga bermanfaat sebagai obat alami untuk 
mengobati rematik, malaria, cacingan, diabetes, insomnia, hasil penelitian Moghadamtousi et al. (2015) menunjukkan bahwa daun sirsak mengandung beberapa senyawa kimia antara lain alkaloid, flavonol triglikosida, dan annonaceous asetogenins. Masyarakat di Desa Yanim dan Braso memanfaatkan daun gatal bintik putih untuk mengatasi pegal-pegal pada tubuh dan mengobati malaria. Daun gatal bintik putih ditemukan tumbuh di daerah kebun. Daun gatal bintik putih juga bermanfaat untuk mengobati luka. Hasil penelitian Simaremare (2014) menunjukkan bahwa daun gatal bintik putih mengandung beberapa senyawa kimia antara lain alkaloid, glikosida dan terpenoid. Getah yang digunakan adalah dari tanaman pohon lipan Pedilanthus tithymaloides, masyarakat di Desa Braso memanfaatkan pohon lipan untuk mengobati luka. Getah daun bermanfaat untuk mengobati keseleo. Hasil penelitian Raveen et al. (2012) menunjukkan bahwa getah dari daun pohon lipan mengandung beberapa senyawa kimia antara lain terpenoid dan fenol. Buah yang digunakan adalah dari tanaman buah merah Pandanus conoideus, masyarakat di Desa Braso memanfaatkan buah merah untuk mengobati penyakit pada organ dalam tubuh. Buah merah juga bermanfaat untuk mengobati malaria, artritis, rematik, serangan jantung, kanker, diabetes, obesitas dan stroke. Hasil penelitian Rohman et al. (2012) menunjukkan bahwa buah merah menghasilkan minyak esensial yang mengandung beberapa senyawa kimia antara lain: antioksidan, richloromethane dan $\beta$-carotene. Biji yang digunakan adalah dari tanaman mahkota dewa Phaleria macrocarpa, masyarakat di Desa Braso memanfaatkan tanaman mahkota dewa untuk mengobati penyakit asma, asam urat, kolesterol, paru-paru basa, batu ginjal dan perawatan sehabis melahirkan. Mahkota dewa juga bermanfaat untuk mengobati kanker serviks, impotensi, diabetes mellitus, alergi, liver, penyakit jantung, rematik, menurunkan tekanan darah tinggi, penyakit kulit, gangguan ginjal, menurunkan kolesterol, dan jerawat. Hasil penelitian Alara et al. (2016) menunjukkan biji mengandung senyawa polifenol, fevicordin dan cucurbitacin.

Pemakaian tumbuhan obat oleh masyarakat, baik pada anak-anak, remaja, orang dewasa dan lanjut usia. Pemakaian tumbuhan obat (dapat dilihat Tabel 3) yang paling banyak digunakan oleh masyarakat sebanyak 2 (dua) jenis tumbuhan yaitu Daun gatal hijau Laportea interrupta dan Daun gatal bintik putih Laportea decumana dengan persentase pemakaian di masyarakat Desa Yanim 22 orang $(73,3 \%)$ dan 20 orang $(66,67 \%)$ di masyarakat Desa Braso. Pemakaian tumbuhan obat yang paling sedikit adalah untuk jenis tumbuhan. Beberapa jenis tumbuhan obat yang dimanfaatkan oleh masyarakat pada kedua desa ini hampir sama, namun ada beberapa jenis tumbuhan juga yang dimanfaatkan oleh masyarakat di desa Yanim, tetapi tidak dimanfaatkan oleh masyarakat di Desa Braso dan sebaliknya. Tumbuhan obat tradisional yang ditemukan di Desa Yanim dan Braso diantaranya terdapat beberapa jenis tumbuhan yang merupakan tumbuhan endemik Papua yaitu daun gatal ungu Dendrocnide peltata, daun gatal hijau Laportea interrupta, daun gatal bintik putih Laportea decumana, daun gatal babi Laportea sp., dan buah merah Pandanus conoideus. Jenis-jenis tumbuhan ini mempunyai potensi yang sangat besar sebagai obat. Tumbuhan daun gatal ini sangat populer di kalangan masyarakat Papua sedangkan tumbuhan buah merah Pandanus conoideus ini khasiatnya sangat besar dan populer di masyarakat Indonesia.

Masyarakat lokal pada beberapa wilayah di Indonesia mengenal adanya dukun atau orang yang dianggap ahli dalam pengobatan tradisional dengan menggunakan potensi dari tumbuh-tumbuhan, namun masyarakat lokal di Distrik Kemtuk Gresi tidak mengenal adanya dukun obat-obatan tradisional, sehingga pemanfaatan tumbuhan 
sebagai obat tradisional diketahui dari orang-orang yang lebih tua atau diwariskan secara turun-temurun.

\section{Cara Pengolahan dan Pemakaian Tumbuhan Obat}

Masyarakat di Desa Yanim dan Braso mengolah atau meramu tumbuhan obat dengan cara direbus, digosok, ditumbuk, diteteskan diremas-remas, dan dikunyah,. Organ tumbuhan yang direbus adalah daun, kulit batang, akar, rimpang dan seluruh organ untuk tumbuh-tumbuhan yang habitusnya berupa herba. Organ tumbuhan yang digosokkan langsung pada tubuh adalah daun, misalnya Daun gatal Dendrocnide peltata, Laportea decumana, L. interrupta dan Laportea sp. untuk mengatasi pegalpegal pada tubuh dan malaria. Organ tumbuhan yang ditumbuk adalah kulit batang, misalnya pada kulit batang tumbuhan Kersen belanda Apeiba tibourbon yang digunakan untuk mengobati bisul. Organ tumbuhan yang diteteskan adalah getah tangkai tanaman Jatropha gossypifolia. Organ tumbuhan yang diremas-remas adalah daun sirih Piper betle untuk mengatasi jerawat pada wajah. Organ tumbuhan yang dikunyah adalah daun muda, misalnya daun Seuseureuhan Piper aduncum untuk mengobati luka. Persentase cara pengolahan tumbuhan obat yang dilakukan dengan cara direbus $(71,4 \%)$, digosok $(8,92 \%)$, ditumbuk $(10,7 \%)$, dikunyah $(3,57 \%)$, diteteskan $(10,7 \%)$, dan diremas-remas $(3,57 \%)$. Pengolahan tumbuhan obat yang paling banyak dilakukan oleh masyarakat di Desa Yanim dan Braso yaitu dengan cara direbus $(69,6 \%)$ dan paling sedikit dengan cara dikunyah-kunyah $(3,57 \%)$ dan diremasremas $(3,57 \%)$.

\section{KESIMPULAN}

Hasil penelitian jenis tumbuhan berkhasiat obat tradisional yang dilakukan di Desa Yanim dan Braso, Distrik Kemtuk Gresi Kabupaten Jayapura menunjukkan bahwa jumlah keseluruhan tumbuhan yang dimanfaatkan oleh masyarakat desa setempat adalah 57 jenis dari 35 Familia dan 2 (dua) Classis yaitu Monocotyledoneae dan Dicotyledoneae. Jumlah jenis tumbuhan obat yang dimanfaatkan di Desa Yanim yaitu 30 jenis dan di Desa Braso 55 jenis. Organ tumbuhan paling banyak dimanfaatkan adalah daun $(66,7 \%)$ dan paling sedikit adalah biji $(1,78 \%)$. Cara pengolahan tumbuhan obat paling banyak dilakukan dengan cara direbus $(73,2 \%)$ dan paling sedikit dengan cara dikunyah-kunyah $(3,57 \%)$ dan diremas-remas $(3,57 \%)$.

\section{UCAPAN TERIMA KASIH}

Penulis mengucapkan banyak terima kasih kepada berbagai pihak yang terlibat dalam penulisan jurnal ini dan juga kepada :

1. Direktorat Jenderal Pendidikan Tinggi (DIRJEN DIKTI)

2. Badan Pengembangan Sumber Daya Manusia (BP SDM) Provinsi Papua

3. Pemerintah Daerah Kabupaten Jayapura yang telah membiayai studi penulis selama di Perguruan Tinggi. 


\section{DAFTAR PUSTAKA}

Alara, OR., JA. Alara and OA. Olalere, 2015. Review on Phaleria macrocarpa Pharmacological and Phytochemical Properties. Artikel Review. Ladoke Akintola University of Technology, P.M.B 4000, Ogbomoso.

Cavestro, L., 2003. Participatory Rural Appraisal Concepts Methodologies and Techniques. Universita' Degli Studi Di Padova. Padua.

Darnaedi, S., dan Nizma. 1995. Pemakaian Jenis Tumbuhan Obat Untuk Obat Tradisional Pada Masyarakat Sunda Kasepuhan Bogor.

Fathoni, A., 2006. Metodologi Penelitian dan Teknik Penyusunan Skripsi. Rineka Cipta. Jakarta.

Gupta, S. K and A. Sharma, 2014. Medicinal Properties of Zingiber officinale Roscoe. Sikkim University. Sikkim. Journal of Pharmacy and Biological Sciences. 9 (5): 124126.

Hidayat, D dan H. Gusti, 2012. Studi Keanekaragaman Jenis Tumbuhan Obat di Kawasan IUPHHK PT. Sari Bumi Kusuma Camp Tontang Kabupaten Sintang. Jurnal Vokasi, Volume 8, Nomor 2. Fakultas Kehutanan Universitas Tanjungpura. Pontianak.

Katno dan S. Pramono, 2006 . Tingkat Manfaat dan Keamanan Tanaman Obat dan Obat Tradisional. Balai Penelitian Tanaman Obat Tawangmang Fakultas Farmasi UGM. Yogyakarta.

Kawengian, L. dan BT. Rumahorbo, 2009. Potensi Vegetasi Non Kayu yang Dimanfaatkan oleh Masyarakat di Distrik Unurum Guay, Kabupaten Jayapura. Jurnal Biologi Papua. Volume 1, Nomor 1. Jurusan Biologi FMIPA Universitas Cendrawasih. Jayapura.

Lucas, K. dan D. Maxey, 2006. Field Test of The Area-Free Cruise Method. http://www.tsiwood.com

Moghadamtousi, SZ., M. Fadaeinasab, S. Nikzad, G. Mohan, H. M. Ali, and H. A. Kadir, 2015. Annona muricata (Annonaceae): A Review of Its Traditional Uses, Isolated Acetogenins and Biological Activities. University of Malaya. Kuala Lumpur. International Journal of Molecular Sciences. (16): 15627-15632.

Pratiwi, SUT., E. Lagendijk, L. Hertiana, T. S. Weert, and C. Van Den Hondel, 2015. Antimicrobial Effects of Indonesian Medicinal Plants Extracts on Planktonic and Biofilm Growth of Pseudomonas aeruginosa and Staphylococcus aureus. Leiden University. Amsterdam. Journal of Horticulture. 2 (1): 2-5.

Raveen, R,. P. Dhayanidhi, K. Dhinamala, S. Arivoli, and S. Tennyson, 2012. Larvicidal Activity of Pedilanthus tithymaloides (L.) Poit (Euphorbiaceae) Leaf Against The Dengue Vector Aedes aegypti (L.) (Diptera: Culicidae). Madras Christian College Chennai. International Journal of Environmental Biology. 2 (2): 36-37. 
Rohman, A., R. Sugeng and YB. Che Man, 2012. Characterizaton of Red Fruit (Pandanus conoideus Lam) Oil. Gadjah Mada University. Yogyakarta. International Food Research Journal 19(2).

Sada, T. J. dan THR. Rosye, 2010. Keragaman Tumbuhan Obat Tradisional di Kampung Nansfori Distrik Supiori Utara, Kabupaten Supiori-Papua. Jurusan Biologi FMIPA Universitas Cendrawasih. Jayapura. Jurnal Biologi Papua. 2 (2).

Setyowati, FM., 2010, Etnofarmakologi dan Pemakaian Tanaman Obat Suku Dayak Tunjung di Kalimantan Timur. Lembaga IImu Pengetahuan Indonesia. Bogor. Artikel Media Litbang Kesehatan.

Simaremare, ES., 2014. Skrining Fitokimia Ekstrak Etanol Daun Gatal(Laportea decumana (Roxb.) Wedd). Program Studi Farmasi Universitas Cendrawasih. Jayapura.

Sundaraganapathy, R. Niraimathi, V. Thangadurai, A. Jambulingam, M. Narasimhan, M. and Deep, A. 2013. Phytochemical Studies and Pharmacological Screening of Sida rhombifolia Linn. Journal for Drugs and Medicines. Volume 5, Nomor 1. Swamy Vivekananda College of Pharmacy. Tiruchengode.

Trimedona, N., H. Nurdin, D. Darwis, and M. Efdi, 2015. Isolation of Triterpenoid from Stem Bark of Pometia pinnata, Forst \& Forst. Andalas University. Balikpapan. Journal of Chemical and Pharmaceutical Research. 7 (11): 225-226.

Umar, Z., 2005. Pemanfaatan Tumbuhan Obat dalam Upaya Pemeliharaan Kesehatan. Fakultas Kedokteran Universitas Sumatera Utara. 